\title{
La construcción de producciones orales en la infancia a partir de imágenes realistas y no realistas*
}

\section{The construction of oral productions in childhood from realistic and unrealistic images}

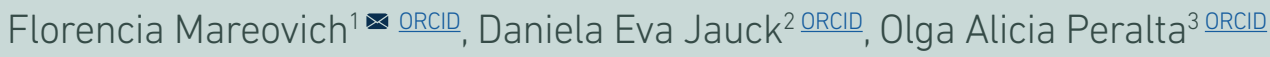 \\ Instituto Rosario de Investigaciones en Ciencias de la Educación \\ Consejo Nacional de Investigaciones Científicas y Técnicas \\ Universidad Abierta Interamericana \\ Argentina
}

Fecha correspondencia:

Recibido: julio 16 de 2019.

Aceptado: marzo 9 de 2020.

Forma de citar:

Mareovich, F., Jauck, D.E., \& Peralta,

0.A. (2020). La construcción de producciones orales en la infancia a partir de imágenes realistas y no realistas. Rev. CES Psico, 13(2), 85-101.

\section{Open access}

(c) Copyright

Licencia creative commons

Etica de publicaciones

Revisión por pares

Gestión por Open Journal System DOI: http://dx.doi.org/10.21615/

cesp.13.2.6

ISSN: 2011-3080

Sobre el artículo:

* Este trabajo fue financiado con subsidios de la Agencia Nacional de Promoción Científica

\section{Resumen}

El objetivo de este trabajo fue examinar la construcción de narrativas de ficción por parte de niños/as de 5 y 6 años de edad a partir de imágenes con distinto nivel de realismo. Analizamos 49 relatos, 24 realizados a partir de imágenes realistas y 25 a partir de imágenes no realistas. Primero clasificamos las producciones en narraciones, descripciones y otras producciones, y analizamos el ordenamiento de las imágenes. La mayoría de los niños/ as que participaron en la condición no-realista construyeron narraciones e identificaron una imagen para el comienzo y otra para el cierre; mientras que los que observaron imágenes realistas construyeron mayormente descripciones y no las organizaron en secuencias. Luego realizamos un análisis de datos textuales consignando: recuento de palabras y segmentos, y recuento de tipos de palabras y segmentos; glosario de palabras y segmentos ordenados según su frecuencia; y respuesta característica (la más significativa de cada grupo). No se encontraron diferencias en el número de palabras y la cantidad de tipos de palabras utilizadas en cada producción, pero sí en las palabras características y en las respuestas que caracterizaron a cada grupo. En las descripciones se utilizaron más sustantivos, mientras que en las narraciones se utilizaron verbos y conectores causales. La respuesta característica de la descripción consistió en una exposición acerca de cada una de las imágenes por separado. La narración presentó un conflicto o estado emocional, una resolución y un cierre. Los resultados muestran que los niños/ as construyeron distintas producciones (narraciones o descripciones) según el tipo de imágenes presentadas.

Palabras claves: Narrativas, Descripciones, Imágenes No Realistas, Imágenes Realistas, Niños, Niñas, Desarrollo Cognitivo, Lenguaje, Aprendizaje.

Comparte

\section{Abstract}

The aim of this paper was to examine the creation of fictional narratives by 5 and 6 year-old children from images with different levels of realism. We analyzed 49 stories, 24 from realistic images and 25 from unrealistic 
y Tecnológica (ANPCyT) otorgado a la tercera autora. Las autoras agradecen la colaboración de los niños e instituciones participantes. Además, las autoras agradecen especialmente la colaboración de la Dra. Nadia Peralta en el análisis de los datos.

\section{Sobre los autores:}

1. Psicóloga. Doctora en Psicología. Investigadora en el Consejo Nacional de Investigaciones Científicas y Técnicas, cumpliendo sus funciones en el Instituto Rosario de Investigaciones en Ciencias de la Educación (IRICE-CONICET-UNR).

\section{Psicóloga. Doctora} en Psicología. Becaria Postdoctoral en el Consejo Nacional de Investigaciones Científicas y Técnicas, cumpliendo sus funciones en el Instituto Rosario de Investigaciones en Ciencias de la Educación (IRICECONICET-UNR).

\section{Psicóloga. Master} in Science. Doctora en Educación. Investigadora Superior en el Consejo Nacional de Investigaciones Científicas y Técnicas, cumpliendo sus funciones en el Instituto Rosario de Investigaciones en Ciencias de la Educación (IRICECONICET-UNR). images. First, the productions were classified into narratives, descriptions and other productions, and analyzed the arrangement of the images. Most of the children who participated in the unrealistic condition created narratives and identified one image for the beginning and another for the ending; while those who observed realistic images mostly made descriptions and did not arrange them into sequences. It was analyzed: number of words and segments and number of kinds of words; glossaries and segments of words sorted by frequency; characteristic responses (the most significant of each group). No differences were found neither in the number of words nor in the number of different word types used in each production. However, differences were found in the characteristic words and in the complete responses that characterized each group. More nouns were used in the descriptions, while verbs and causal connectors were used in the narratives. The characteristic response of the description consisted in a presentation of the images separately. The narrative introduced a conflict or emotional state, a resolution and a closure. The results showed that the children developed different productions (narrations or descriptions) according to the type of images they were exposed.

Keywords: Narratives, Descriptions, Unrealistic Pictures, Realistic Picture, Children, Cognitive Development, Language, Learning.

\section{Introducción}

En la cultura occidental actual es sumamente valorada la interacción con libros ilustrados en la primera infancia. La oferta de libros para niños/as es muy amplia. Algunos libros están compuestos por imágenes que se parecen más a la realidad, mientras que otros presentan animales o plantas con características antropomórficas, monstruos o criaturas imaginarias.

Investigaciones recientes han señalado que cuando se utilizan libros ilustrados para enseñar palabras y conceptos, el realismo de las imágenes es sumamente beneficioso (ej.., Ganea et al., 2009; Ganea, Bloom-Pickard, \& DeLoache, 2008; Mareovich \& Peralta, 2015, 2016; Mareovich, Taverna, \& Peralta, 2015).

En virtud de esta evidencia nos preguntamos si el realismo de las imágenes también facilitaría la construcción de narrativas de ficción por parte de niños/as de 5 y 6 años de edad. Si bien la construcción de narrativas en la infancia ha sido estudiada ampliamente (ej.., Alam \& Rosemberg, 2015, 2016; Bruner, 1986; Carmiol \& Sparks, 2014; Hess \& Prado, 2013), ha sido poco explorado qué tipo de imágenes promueven la construcción de distintos tipos de producciones orales (ej. Bornens, 1990; Shapiro \& Hudson, 1991).

\section{Las narraciones}

El término narrativa refiere a una gran variedad de discursos orales y escritos. Algunos de ellos relatan hechos pasados o futuros, otros son ficciones. Podríamos decir que la narrativa es la organización temporal real o imaginaria de eventos sucesivos (McCabe \& Peterson, 1991). La producción de textos narrativos conlleva un despliegue de habilidades cognitivas verbales y no verbales (ej. Berman \& Katzenberger, 2004; Bornes, 1990; Karmiloff-Smith, 1985). Esta tarea implica una combinación de procesos como hacer inferencias, identificar ideas principales, resumir, predecir, monitorear y dar marcha atrás, comprender las secuencias causales y temporales (Bornens, 1990; Pressley et al., 1994; Snow \& Ninio, 1986). 
Pág 87

La posibilidad de construir narrativas por parte de niños y niñas se gesta en contexto y gracias a prácticas sociales (ej. Bruner, 1986; Nelson, 1996). Las madres, padres y cuidadores guían a sus niños/as para que construyan narrativas. Además, hay ciertas prácticas culturales propias de occidente que son el molde para la construcción de narrativas. Una de esas prácticas es la lectura compartida de libros ilustrados.
Según Stein y Gleen (1979) una narrativa, de hechos reales o de ficción, posee una gramática específica, es decir, una secuencia de elementos indispensables para organizar un relato. La historia debe contar con una introducción, una descripción de los estados emocionales y cognitivos de los personajes, el planteamiento de un conflicto o estado emocional y un plan para la resolución del mismo y, finalmente, una conclusión.

Desde un punto de vista lingüístico las narrativas requieren un dominio de ciertas estructuras como conectores temporales y causales (Alarcon-Neve \& Auza-Benavides, 2015). Es decir, para que una narración sea comprendida se requiere que la producción sea presentada en un contexto temporal y espacial determinado, que explicite vínculos causales entre los fenómenos, metas y motivaciones de los personajes (Peterson \& McCabe, 1994).

Las narrativas de ficción se construyen sobre la base de eventos pasados y futuros de la vida cotidiana (Fivush, Haden, \& Reese, 2006; Nelson, 1996; Peterson \& McCabe, 1983). Esto adquiere todo su sentido si pensamos que para construir una narración de ficción se requiere un distanciamiento cognitivo (Sigel, 1997), despegarse no solo del aquí y el ahora (como puede ocurrir también en narrativas de hechos pasados y futuros) sino, además, pensar e imaginar mundos posibles y eventos que no han ocurrido y, probablemente, no ocurrirán jamás. La ficción literaria no se refiere necesariamente a cosa alguna en el mundo, sino que otorga su sentido a las cosas (Bruner, 2013).

La posibilidad de construir narrativas por parte de niños y niñas se gesta en contexto y gracias a prácticas sociales (ej. Bruner, 1986; Nelson, 1996). Las madres, padres y cuidadores guían a sus niños/as para que construyan narrativas. Además, hay ciertas prácticas culturales propias de occidente que son el molde para la construcción de narrativas. Una de esas prácticas es la lectura compartida de libros ilustrados.

\section{Las narrativas a partir de imágenes}

Paris y Paris (2003) plantean que, en el seno de las interacciones con libros ilustrados que se despliegan cotidianamente en el hogar o en la escuela, los niños/as aprenden a "leer" las imágenes para construir un significado narrativo. Cuando un niño/a observa una secuencia de imágenes construye el significado del relato, tanto a partir de la información provista por las imágenes como de su experiencia previa con imágenes y con historias similares. El niño/a entonces integrará los significados que extraiga de cada una de las imágenes y establecerá vínculos entre eventos y personajes.

Diversos estudios (ej.., Alam \& Rosemberg, 2015, 2016; Bornens, 1990; Piaget, 1946; Shapiro \& Hudson, 1991) han utilizado imágenes para propiciar la construcción de narrativas por parte de niños/as pequeños. Al respecto, Shapiro y Hudson (1991) encontraron que las características de las imágenes producen la utilización de diferentes tipos de conectores. Por ejemplo, si las imágenes presentan conflictos y su posterior resolución, los niños y niñas de 4 y 5 años construían historias coherentes y cohesionadas, propiciaban tramas secuenciales causales utilizando conectores causales y adversativos. Por el contrario, cuando las imágenes presentadas a los niños/as no representaban conflictos los niños/as describían las imágenes utilizando conectores más simples y estructuras menos sofisticadas. 
Pág 88

Las imágenes se han utilizado con una variedad de propósitos, para estudiar los procesos de aprendizaje, analizar o comprender el mundo mental a partir de técnicas proyectivas, medir habilidades cognitivas (como la inteligencia, la percepción, la atención, la memoria), entre otros. Sin embargo, tal como lo señalaran Trautner y Milbrath (2008), la exploración en torno al estatus simbólico de las imágenes es relativamente reciente.
Piaget y colaboradores (Margairaz \& Piaget, 1925, en Bornens, 1990; Piaget, 1946) estudiaron la construcción de historias a partir de la presentación de imágenes en niños y niñas de 4 a 12 años. Los autores encontraron que recién a los 7-8 años lo niños/as reconocían la identidad de un personaje a lo largo de la secuencia. Piaget (1946) explica estos resultados planteando que los niños/as menores de 7 años, quienes se encuentran en el estadio pre-operacional, no pueden organizar en orden las secuencias.

Sin embargo, otros estudios señalaron que niños/as menores de 7 años sí ordenaban la secuencia de las imágenes y armaban historias (ej., Brown, 1975; Brown \& French, 1976); e incluso lograban inferir las consecuencias de una serie temporal (Brown \& French, 1976; Schimidt \& Paris, 1978). Bornens (1990) plantea que comprender una secuencia de imágenes es una tarea muy compleja porque el niño/a debe acceder a un sistema de representaciones espacial usado para representar tanto el tiempo como el espacio. La autora estudió la capacidad de niños/as de 3 a 6 años de ordenar historias, reconocer la identidad de los personajes y unir las imágenes aisladas para construir una narración. Utilizando sets de imágenes desordenadas en las que aparecían personajes con características antropomórficas, encontró que las imágenes son consideradas al comienzo como estáticas y solo gradualmente el niño comprende su dinámica y vincula unas imágenes con otras. Es decir, entre los 4 y 8 años los niños y niñas aprenden a identificar las relaciones, implícitas o explícitas, entre imágenes y a integrarlas para construir significados (ej.., Bornens, 1990; Paris \& Paris, 2003; Schmidt, Paris, \& Stober, 1979).

También, Berman y Katzenberger (2004) investigaron la construcción de narrativas por parte de preescolares a partir de sets de imágenes desordenadas. Trabajaron con niños y niñas de 4 a 6 años y utilizaron un grupo control constituido por niños/as de 10 años, evaluando la organización de las imágenes en una secuencia narrativa, el nivel de organización del texto construido y las estrategias utilizadas para reconocer la identidad de los personajes. En relación con la organización de las imágenes, mientras que los niños/as de 10 años ordenaron las imágenes de manera esperada, muy pocos preescolares lo hicieron ( $5 \%$ de 4 años, $12 \%$ de 5 años y $23.6 \%$ de 6 años). En cuanto a la producción del texto, los autores identificaron tres niveles: 1) prenarrativa, producciones que describen el contenido las imágenes de manera estática y sin vincular unas imágenes con otras; 2) narración local, relatos que expresan de manera lineal una relación temporal con dos eventos consecutivos pero sin integrar todas las imágenes, 3) estructura global, integración jerárquica de todos los eventos que transcurren en las distintas imágenes con una organización narrativa elaborada. Estos tres niveles en la producción de narrativas mostraron una clara relación con la edad. Mientras que los niños/as de 4 años realizaron producciones prenarrativas, los niños/as de 5 y 6 construyeron narraciones locales. Pocos preescolares alcanzaron el nivel de "estructura global". En concordancia con la investigación de Bomens (1990), pocos niños de 4 años/as reconocieron al mismo personaje en la secuencia narrativa.

\section{Las imágenes como símbolos}

Las imágenes se han utilizado con una variedad de propósitos, para estudiar los procesos de aprendizaje, analizar o comprender el mundo mental a partir de técnicas proyectivas, medir habilidades cognitivas (como la inteligencia, la percepción, la atención, la memoria), entre otros. Sin embargo, tal como lo señalaran Trautner y Milbrath (2008), la exploración en torno al estatus simbólico de las imágenes es relativamente reciente. 
Pág 89

Poco a poco los niños y niñas comienzan a comprender y a utilizar simbólicamente las imágenes entre los 18 y 30 meses (ej., DeLoache, 2004; DeLoache \& Burns, 1994; DeLoache, Peralta, \& Anderson, 1999). La relación imagen-referente, es decir, la entidad que representa la imagen se ve afectada por diversas variables como la edad, la similitud perceptual entre el símbolo y el referente, el tipo de actividad en la que están involucrados estos símbolos, entre otras.
La tardía indagación acerca de las imágenes cómo símbolos se basa en la presunción de la simpleza que envuelve a estas representaciones. Se ha igualado percepción con comprensión simbólica de imágenes. Sin embargo, hay un abismo entre ambos procesos. El primero se basa en el reconocimiento perceptual, que para algunos autores es innato o con muy poco desarrollo. La comprensión simbólica, por el contrario, supone una combinación de habilidades cognitivas, sociales y perceptuales (Sigel, 1978).

Poco a poco los niños y niñas comienzan a comprender y a utilizar simbólicamente las imágenes entre los 18 y 30 meses (ej., DeLoache, 2004; DeLoache \& Burns, 1994; DeLoache, Peralta, \& Anderson, 1999). La relación imagen-referente, es decir, la entidad que representa la imagen se ve afectada por diversas variables como la edad, la similitud perceptual entre el símbolo y el referente, el tipo de actividad en la que están involucrados estos símbolos, entre otras.

Un logro importante en el desarrollo de la comprensión de imágenes es establecer que las personas y objetos representados en ellas pueden existir en el mundo real. Así, es posible extraer información para conocer el mundo real y aprender. Investigaciones recienten han estudiado qué tipo de imágenes facilita u obstaculiza el aprendizaje de palabras y conceptos. La similitud perceptual entre imagen y referente mostró ser un factor decisivo para ayudar a los niños/as a conectar la palabra aprendida con un objeto real (ej., Ganea et al., 2009, Ganea et al., 2008; Mareovich \& Peralta, 2015, 2016; Mareovich et al., 2015).

El realismo de las imágenes --cuán similares son estas representaciones a sus referentes-- es crucial si estas representaciones tienen la función de evocar objetos o eventos reales o posibles, ya sean pasados o futuros. Pero las imágenes también pueden referir a entidades que no existen, no han existido y son imaginarias, cuya existencia es imposible o improbable, por ejemplo, un unicornio (DeLoache \& Burns, 1994; DeLoache, Pierroutsakos, \& Troseth, 1996). Por lo tanto, si ya no pensamos en las imágenes como vehículo para el aprendizaje sino como medios para comprender y construir narrativas de ficción: ¿qué tipo de imágenes posibilitarían la construcción de narraciones de ficción por parte de niños/as?

Numerosos estudios muestran que los niños y niñas construyen narrativas a partir de imágenes (ej., Berman \& Katzenberger, 2004; Schmidt, Paris, \& Stober, 1979); sin embargo, pocos han explorado específicamente qué tipo de imágenes propician la construcción de narrativas de ficción por parte de niños/as preescolares (ej. Bornens, 1990; Shapiro \& Hudson, 1991). En este sentido, la presente investigación tiene como objetivo examinar la construcción de narrativas de ficción por parte de niños/as de 5 y 6 años a partir de imágenes con distinto grado de realismo.

\section{Metodología}

Se diseñaron dos condiciones experimentales en función de las imágenes presentadas: realista y no-realista. En la condición realista las imágenes mostraban a personas con sus mascotas, mientras que la condición no-realista mostraban animales con características antropomórficas.

\section{Participantes}

Cuarenta y nueve niños y niñas ( $M=5.9$ años, DT= 3.4 meses, Rango=5.4-6.8 años). En la condición no-realista participaron 24 niños ( $M=5.9$ años, $D T=3.6$ meses, Rango=5.5-6.8 años), 16 niñas y 9 niños; y en la condición de imágenes realistas participaron 25 niños $(M=5.9$ años, $D T=3.4$ meses, Rango=5.4-6.3 años), 13 niñas y 11 niños. 
Los participantes eran de nivel sociocultural medio y concurrían a una escuela de gestión privada de la ciudad de Rosario (Argentina). A fin de conocer las características de los participantes y sus contextos de crianza realizamos una encuesta breve. La edad media de las madres era 37 años y de los padres 38. El nivel educativo de madres y padres era mayoritariamente universitario, y casi todos trabajaban en su profesión, en tareas administrativas o en comercios. Las madres y padres reportaron que sus niños/as, con mayor o menor frecuencia, estaban expuestos a la rutina de lectura de libros ilustrados. Todos los niños y niñas presentaban un desarrollo esperado para su edad, según los registros de las instituciones y los informes docentes.

Se obtuvo el consentimiento informado y escrito, tanto de los padres como de las instituciones, no de los niños/as debido a su edad. Sin embargo, se consultaba a los participantes antes de comenzar el trabajo si estaban dispuestos a realizar la actividad o no, respetando su voluntad.

\section{Materiales}

Utilizamos 12 dibujos impresos en papel común de 29,7 cm x $21 \mathrm{~cm}$ (Figura 1) agrupados en dos sets compuestos por 6 imágenes: realistas y no-realistas. Ambos sets mostraban la organización de una fiesta y su posterior realización.

En el set de imágenes realistas (Figura 1) se podían observar personas interactuando con animales. Una imagen representaba a una niña con su perro y gato preparando invitaciones de cumpleaños. Tres imágenes representaban personas con su mascota recibiendo una invitación para la fiesta. Otra imagen presentaba a la niña con sus mascotas con cara de preocupación. Por último, una última imagen muestra a la niña recibiendo a todos sus amigos, con sus respectivas mascotas, en su fiesta.

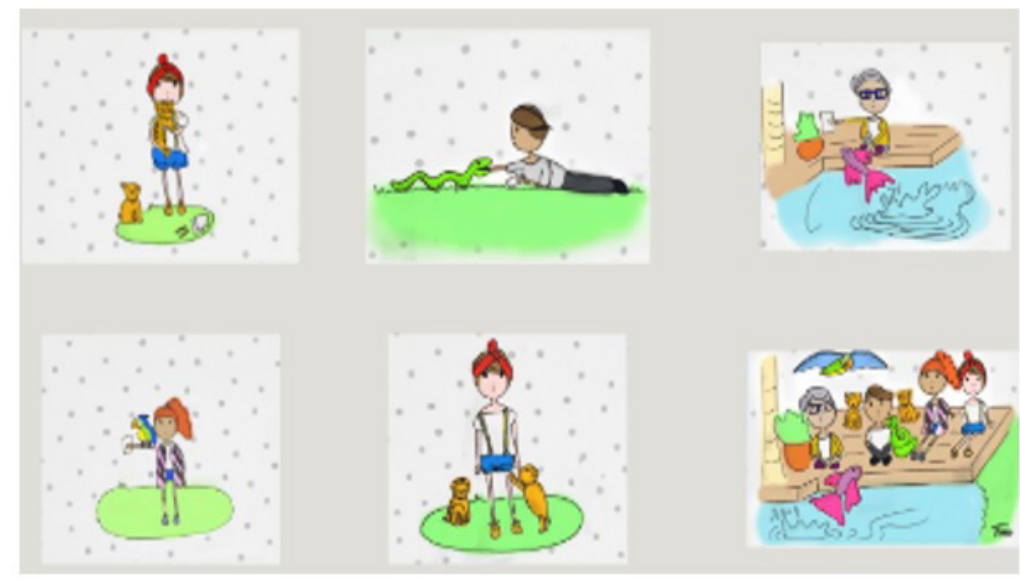

Figura 1. Sets de imágenes condición realista.

Las imágenes no-realistas (Figura 2) contenían animales con características antropomórficas interactuando entre sí (ej., un gato vestido parado en dos patas). Los sets presentaban información similar al anterior, pero en distinto formato. En una imagen se observaba a un perro y un gato preparando invitaciones de cumpleaños. Tres imágenes representaban a animales recibiendo una invitación para la fiesta. Otra imagen presentaba al perro y gato preocupados. La sexta imagen mostraba a todos los animales reunidos celebrando la fiesta. 


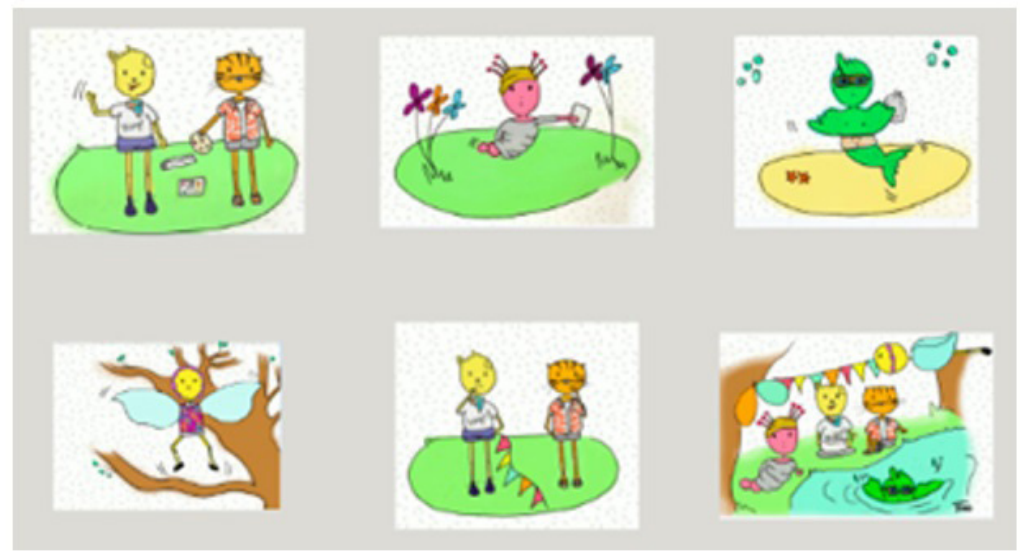

Figura 2. Sets de imágenes condición no-realista.

\section{Procedimiento}

La tarea se desarrolló en un aula de la escuela a la que concurrían los niños y niñas. Los niños/as fueron evaluados individualmente en todos los casos por la misma investigadora. El procedimiento constaba de dos fases:

Familiarización. Antes de comenzar la tarea, la investigadora preguntaba al niño o niña si le gustaban los cuentos y cuáles eran sus preferidos. Además, le pedía que contara brevemente su cuento preferido. Todos los participantes relataron su cuento preferido. Esto indicaría que todos los niños podían narrar una breve historia.

Prueba. La investigadora presentaba al niño/a un set de imágenes (realista o no-realista, según condición) de manera desordenada. Luego decía: ¿Has visto estos dibujos?, me dijeron que con estos dibujos se puede armar un cuento. ¿Me cuentas un cuento? ¿Cómo lo armarías? La niña o niño debía ordenar las imágenes y luego construir un relato. Además, se invitaba al niño/a tomar una fotografía de su cuento a fin de registrar la manera en que había ordenado las imágenes. Las interacciones fueron audiograbadas y luego transcriptas a protocolos escritos para su posterior codificación y análisis.

\section{Codificación}

El sistema de categorías fue elaborado a partir de dimensiones teóricas que consideramos pertinentes en cuanto al contenido y propósito de los mensajes que transmitieron los niños/as en la tarea; además, se enriqueció con el sistema de codificación utilizado en investigaciones previas (Berman \& Katzenberger, 2004; Bornens, 1990; Paris \& Paris, 2003). A partir de los datos surgidos de las observaciones adaptamos y refinamos el sistema a los fines de captar las características propias del discurso de los niños/as y abordar el objetivo de la investigación. Como resultado, algunas categorías se agregaron y otras, inicialmente consideradas; luego fueron integradas en categorías más inclusivas o eliminadas debido a su baja o nula frecuencia. Para realizar esta tarea nos basamos en los criterios generales del método comparativo constante (ej., Glaser \& Strauss, 1967; Strauss \& Corbin, 1990).

El sistema de categorías de las producciones quedo definido así:

1. Narración: relato verbal con un comienzo, un conflicto o estado emocional, y una resolución del conflicto o cambio de estado emocional. Por otro lado, como la tarea consistía en la presentación de 6 imágenes, resultó además de interés observar si los niños/a las integraban entre sí como parte del relato. 
2. Descripción: producciones verbales que refieren a las características o propiedades presentes en las imágenes (ej. niño rojo) o a eventos que acontecen en una imagen (ej. vino el gato). Estos relatos tienen más o menos detalles, pero no integran la información proveniente de las diversas imágenes de la serie.

3. Otras producciones: producciones verbales escuetas consistentes solo en palabras sueltas o en comentarios que no remitían a las imágenes.

El Cuadro 1 presenta el sistema de categorías utilizado, con ejemplos.

\section{Análisis de datos}

Se realizaron dos tipos de análisis. Primero se clasificó y comparó el tipo de producciones según condición y luego se realizó un análisis del contenido de las producciones.

Comparación de tipo de producciones según condición. Las producciones de los niños/ as fueron clasificadas por dos jueces según las siguientes categorías: 1-Narración, 2- Descripción, 3- Otras producciones. Las clasificaciones de los jueces tuvieron una alta concordancia (Kappa $\geq .85$ ).

Una vez clasificada cada producción comparamos la distribución del tipo de producción por condición, imágenes realistas, imágenes no realistas. Posteriormente cotejamos el orden de las imágenes por condición (imágenes realistas-no realistas) y por tipo de producción (descripciones, narraciones y otras producciones). Los análisis de esta primera etapa se realizaron mediante la prueba Chi cuadrado utilizándose programa SPSS ${ }^{\circledR}$ versión 20.

Análisis de contenido de las producciones. En esta etapa analizamos cualitativamente las producciones. Realizamos un Análisis de Datos Textuales utilizando el Análisis Multidimensional de Datos con el programa SPAD (ej.., Beaudouin, 2016; Moscoloni, 2005; Peralta, Castellaro, \& Santibáñez, 2020), que permite comparar las producciones de participantes o de grupos de participantes mediante las frecuencias relativas de palabras y frases cortas (segmentos). Este análisis se realizó en tres pasos:

1. Recuento de cantidad total de palabras y segmentos y cantidad de tipos de palabras y segmentos-es decir, el número de diferentes tipos de palabras y segmentos que utilizaban los niños- de los distintos tipos de producciones (narraciones, descripciones y otras producciones):

2. Construcción de glosarios de palabras y segmentos característicos ordenados en función de la frecuencia. Las palabras y segmentos características son aquellos cuya frecuencia de utilización dentro de cada uno de los grupos (narraciones, descripciones y otras producciones) es significativamente mayor a su uso en la muestra total (Aluja \& Morineau, 1999).

3. Análisis de las respuestas características de cada tipo de producción (descripciones y narraciones), a fin de analizar su empleo en contexto. Para realizar este análisis primero se calcula el perfil léxico medio del grupo. La respuesta más característica de un grupo es la más próxima al perfil medio del texto que se obtiene calculando la media de los perfiles de las respuestas del mismo. Este análisis permite un retorno al texto para entender el modo en que los niños/as han construido cada una de las producciones (Moscoloni, 2005). No se analizaron las respuestas características de las otras producciones debido a su brevedad. 


\section{Resultados}

\section{Tipo de producción según condición}

Los resultaron mostraron que la mayoría de los niños y niñas en la condición no-realista realizaron narraciones, mientras que los niños y niñas que trabajaron con imágenes realistas construyeron, en mayor medida, descripciones. La diferencia entre ambas condiciones es significativa (Tabla 1).

Tabla 1. Frecuencia y porcentaje del tipo de producción por condición. Comparación de producciones mediante Prueba

\begin{tabular}{|c|c|c|c|c|c|c|c|}
\hline \multirow{3}{*}{ Condición } & \multicolumn{6}{|c|}{ Producción } & \multirow{3}{*}{$X^{2}$} \\
\hline & \multicolumn{2}{|c|}{ Narración } & \multicolumn{2}{|c|}{ Descripción } & \multicolumn{2}{|c|}{ Otras producciones } & \\
\hline & $n$ & $\%$ & $n$ & $\%$ & $n$ & $\%$ & \\
\hline No-realista & 18 & 78 & 3 & 13 & 2 & 9 & \multirow{2}{*}{.000} \\
\hline Realista & 5 & 20 & 20 & 80 & 0 & 0 & \\
\hline
\end{tabular}

Respecto a la evaluación de la estructura de las narraciones, los resultados indican que trabajando con imágenes no-realistas los niños/as construyeron narraciones completas, con un claro inicio, un conflicto y una resolución. Además, integraron dinámicamente la información presentada construyendo significados que se plasmaron en narraciones de ficción. Los niños/os de la condición realista, por su parte, construyeron descripciones (con mayor o menor nivel de detalle).

Si agrupamos las producciones según condición, realista versus no-realista, y analizamos el ordenamiento de las imágenes encontramos diferencias significativas. Es decir, gran parte de los niños/as que participaron en la condición no-realista que construyeron narraciones identificaron claramente una imagen para el comienzo, una imagen en el centro de la trama y otra para el cierre. Las otras tres imágenes ocupaban lugares menos definidos.

Al comparar el modo de ordenamiento de las imágenes por tipo de producción, narraciones versus descripciones, también encontramos diferencias significativas, mostrando que los niños/as que observaron imágenes realistas y construyeron descripciones no las organizaron en una secuencia.

\section{Análisis de contenido de las producciones}

Cantidad y tipos de palabras y segmentos. En el tipo de producción categorizado como descripciones se presentaron más cantidad de palabras y segmentos, y cantidad de tipos de palabras que en el de narraciones (Tabla 2). Sin embargo, esta diferencia no es amplia, lo que nos llevaría a pensar que lo que distingue los tipos de producciones es su estructura y organización, como se refleja en el análisis anterior.

Glosario de palabras y segmentos característicos. Si analizamos las palabras y segmentos característicos en las narraciones observamos que remiten a la organización de la fiesta, la invitación de los animales al evento, la imposibilidad de asistencia y luego la resolución de la situación problemática (ver Cuadro 1, producción característica de Narraciones). La palabra más usada es porque (Tabla 3), palabra que introduce una explicación o justificación sobre un evento que está reflejado en las 
imágenes. También se utilizó con frecuencia la palabra vino, conjugación del verbo venir, aludiendo, por lo general, a la asistencia a la reunión (Tabla 3).

Tabla 2. Distribución de palabras y segmentos en los grupos

\begin{tabular}{lccc}
\hline Tipo de producciones & $\begin{array}{c}\text { Cantidad de palabras } \\
\text { y segmentos }\end{array}$ & $\begin{array}{c}\text { \% del total de palabras } \\
\text { y segmentos }\end{array}$ & $\begin{array}{c}\text { Cantidad de tipos de } \\
\text { palabras y segmentos }\end{array}$ \\
\hline Narraciones & 1490 & $44.02 \%$ & 308 \\
\hline Descripciones & 1889 & $55.72 \%$ & 352 \\
\hline Otro & 9 & $2.3 \%$ & 3 \\
\hline
\end{tabular}

Tabla 3. Palabras y segmentos característicos en las Narraciones

\begin{tabular}{ccccc}
\hline Palabras y segmentos & Porcentaje interno & Porcentaje global & V. Test & Prueba \\
\hline porque & 1.82 & 0.85 & 3.780 & 0.000 \\
\hline no & 1.95 & 1.02 & 3.214 & 0.001 \\
\hline cumpleaños & 0.78 & 0.34 & 2.461 & 0.007 \\
\hline a & 3.64 & 2.56 & 2.371 & 0.009 \\
\hline a la & 0.91 & 0.46 & 2.160 & 0.015 \\
\hline vino & 0.65 & 0.28 & 2.147 & 0.016 \\
\hline Vino el & 0.65 & 0.28 & 2.140 & 0.016 \\
\hline El agua & 0.65 & 0.28 & 2.140 & 0.016 \\
\hline fiesta & 1.43 & 0.85 & 2.060 & 0.020 \\
\hline
\end{tabular}

En el caso de las descripciones, como se observa en la Tabla 4, las palabras características refieren a los nombres de los animales (serpiente, loro, animales) y deícticos que se utilizan para señalar la escena a describir (acá, este).

Tabla 4. Palabras y segmentos característicos en las Descripciones

\begin{tabular}{lcccc}
\hline Palabras y segmentos & Porcentaje interno & Porcentaje global & V. Test & Prueba \\
\hline Una serpiente & 1.22 & 0.68 & 3.086 & 0.001 \\
\hline serpiente & 1.93 & 1.25 & 2.795 & 0.003 \\
\hline este & 2.53 & 1.82 & 2.415 & 0.008 \\
\hline acá & 1.32 & 0.85 & 2.225 & 0.013 \\
\hline animales & 1.32 & 0.85 & 2.225 & 0.013 \\
\hline Un & 6.79 & 5.69 & 2.169 & 0.015 \\
\hline de & 1.72 & 1.19 & 2.148 & 0.016 \\
\hline Todos los & 0.71 & 0.40 & 2.101 & 0.018 \\
\hline loros & 1.42 & 0.97 & 2.004 & 0.023 \\
\hline
\end{tabular}


Análisis de respuestas características. Si observamos la respuesta característica de la condición narraciones podemos encontrar algunas de las palabras o segmentos característicos (ver Cuadro 1, resaltado en itálica). En esta producción se contempla un conflicto (no podía festejarse la fiesta) y una resolución y cambio de estado.

La respuesta característica de la condición descripciones también refleja algunas de las palabras o segmentos característicos del grupo (ver Cuadro 1, resaltado en itálica). Este tipo de producción se caracteriza por utilizar gran cantidad de adjetivos y sustantivos. Si bien se describen acciones y estados (está dibujando, mojó el papel, estaban alegres) no hay una integración entre las distintas escenas.

Cuadro 1. Respuesta característica dentro del grupo de Narraciones y Descripciones

\begin{tabular}{ll}
\hline Grupo & Respuesta característica \\
\hline \multirow{3}{*}{ Narración } & $\begin{array}{l}\text { Este es el cumpleañero que viene al cumpleaños. Después están tristes porque } \\
\text { no saben dónde... porque no vino el cumpleañero y se canceló. Así que vino el } \\
\text { cumpleañero y le estaban haciendo un dibujo. Y después vino el hada. Y una niñita } \\
\text { estaba atrapada. Y esta la salvo. El hada salvó a la nena que estaba atrapada. Y al } \\
\text { final pudieron festejar el cumpleaños. }\end{array}$ \\
& $\begin{array}{l}\text { Puede ser... Muy bien. Una vez una señora encontró un pez y una piña. Y después } \\
\text { se encontró un canario y esto. Y se le mojó un papel. Y después se encontró la } \\
\text { niña un gato y un perro, y tenía la niña zapatos amarillos y pantalones azules. Y } \\
\text { este cosito de acá son amarillos y esto es rojo. Esto es cuando... Acá las mascotas } \\
\text { estaban alegres. Y acá la niña estaba dibujando. Y acá se encontró la señora con } \\
\text { esta niña que tenía zapatos violetas y el pantalón también son azules, y su remera } \\
\text { es blanca y también tenía un papel. Y también tenía un loro que repite las cosas. Y } \\
\text { acá se encontraron todos, el pez, este de aquí y esto está allá también. Este es el } \\
\text { loro, y este es el gato y esto... el perro. Y acá el niño se encontró con una serpiente. Y } \\
\text { al final la serpiente se comió el brazo y después le pusieron un brazo de metal. }\end{array}$ \\
\hline
\end{tabular}

Analizando ambos tipos de producciones, narración y descripción, podemos apreciar que en la descripción se utilizan más palabras, es un producto más extenso que la narración. Además, en la descripción se presentan acciones, se describen en profundidad el aspecto y el accionar de los participantes; se reconoce la identidad de algunos de los personajes presentes en diversas imágenes. Utilizamos la categoría de descripción en sentido amplio haciendo alusión tanto a la enumeración de elementos que aparecen en las imágenes y la explicación acerca de sus características, como a la presentación de conflictos o sentimientos representados en las imágenes, pero sin la resolución de los mismos o cambio de estado de los personajes. Es decir, es un relato estático sobre las características de las imágenes que, además, no integra la información procedente de una imagen con la información observada en otra.

En la narración, por el contrario, podemos notar un hilo conector entre los relatos que se producen a partir de las diversas imágenes. Toda la producción del niño/a refleja una integración, un cambio de estado y la resolución de un conflicto. La narración presenta, aunque de manera sencilla, un conflicto (están tristes porque el cumpleaños se canceló), una resolución (el hada salvó a la nena atrapada) y un cierre (al final pudieron festejar el cumpleaños). 
Los resultados más relevantes sugieren que los distintos tipos de imágenes propician distintos tipos de producciones. Las imágenes más realistas posibilitan la construcción de descripciones, más o menos detalladas, sobre los elementos representados; y las imágenes menos realistas, que presentan animales con características antropomórficas, posibilitan la construcción de narraciones de ficción. Estas producciones no se diferencian por la cantidad, tipos de las palabras o segmentos utilizados, sino por sus palabras características y su estructura, que se aprecia en la respuesta característica.

\section{Discusión}

El objetivo de este trabajo fue examinar las producciones orales que construyen los niños y niñas de 5 y 6 años de edad a partir de dos tipos de imágenes, más realistas o menos realistas. Los resultados más relevantes sugieren que los distintos tipos de imágenes propician distintos tipos de producciones. Las imágenes más realistas posibilitan la construcción de descripciones, más o menos detalladas, sobre los elementos representados; y las imágenes menos realistas, que presentan animales con características antropomórficas, posibilitan la construcción de narraciones de ficción. Estas producciones no se diferencian por la cantidad, tipos de las palabras o segmentos utilizados, sino por sus palabras características y su estructura, que se aprecia en la respuesta característica.

Para clasificar las producciones tuvimos en cuenta dos criterios: la estructura de la producción y el ordenamiento de las imágenes. Las narraciones correspondían a producciones que mostraban un claro inicio, un conflicto o estado emocional, y una resolución de conflicto o cambio de estado emocional (Stein \& Gleen, 1979). Las descripciones, por el contrario, consistían en una exposición acerca de los elementos que aparecían en las imágenes y sus características, y también acerca de eventos que acontecían en las diversas imágenes. Asimismo, siguiendo estudios previos (ej.. Berman \& Katzenberger, 2004; Bornens, 1990; Paris \& Paris, 2003), para clasificar las producciones como narraciones deben integrar la información presente en varias imágenes para construir el relato; mientras las descripciones se caracterizan por una enumeración, más o menos detallada, de los elementos o conflictos que se presentan en cada una de las láminas de manera aislada; es decir, no integran la información reflejada por las diversas imágenes.

Los niños y niñas que trabajaron con imágenes no-realistas produjeron narraciones completas, con un claro inicio, un conflicto y una resolución; lo que coincide con estudios previos (ej., Peterson \& McCabe, 1983, Stein \& Gleen, 1979). La integración de la información extraída de cada una de las imágenes refleja que interpretaron las imágenes de forma dinámica (Bornens, 1990; Paris \& Paris, 2003). Por el contrario, ante imágenes realistas la mayoría de los niños/as construyó descripciones, es decir, no integraron la información presentada en las imágenes. Con relación al ordenamiento de las imágenes, los niños/as que participaron en la condición no-realista y produjeron narraciones ordenaron las imágenes identificando claramente una imagen para el inicio, una para el desarrollo y otra para el desenlace; resultados que concuerdan con estudios previos que señalan que los niños/as preescolares organizan imágenes en secuencias (ej., Brown \& French, 1976; Brown, 1975).

Por el contrario, los niños/as que participaron en la condición realista y construyeron descripciones no ordenaron las imágenes en una secuencia, hallazgo coherente con investigaciones realizadas por Piaget y colaboradores (Margairaz \& Piaget, 1925, citado en Paris \& Paris, 2003; Piaget, 1946), quienes encontraron que los niños/as de estas edades, específicamente niños en la etapa pre-operatoria, no ordenaban las secuencias de imágenes. Cabe señalar que los niños/as que participaron de esta condición contaron a la experimentadora su cuento favorito en la fase de familiarización, lo que indicaría que pueden, en otros contextos, construir historias.

La diferencia que presentan las producciones de los niños/as por condición, considerando su estructura gramatical y el ordenamiento de las imágenes, indicaría que el tipo de imágenes influye en el tipo de producciones que realizan. Estos resultados están en línea con trabajos que destacan la importancia de estudiar la comprensión y 
El análisis de contenido de las producciones más características permite observar que la descripción es más extensa y con mucho detalle; describe en profundidad las imágenes y las características de los personajes, mientras la narración es más escueta y con menos detalles sobre los personajes. Esto nos hace pensar que las narraciones y las descripciones son producciones diferentes, por lo que la descripción no precedería a la narración. organización de series de imágenes para conocer cómo los niños y niñas construyen y, también comprenden, narraciones (ej., Berman \& Katzenberger, 2004; Bornens, 1990; Paris \& Paris, 2003). Para desentrañar en qué consisten las diferencias entre tipo de producciones, descripciones y narraciones, se realizó un análisis de contenido; evaluamos la cantidad de palabras y segmentos y la cantidad de tipos de palabras, y no se encontraron diferencias significativas.

El análisis de las palabras y segmentos característicos de narración y descripciones nos muestran diferencias cualitativas entre producciones. En las narraciones predominan las palabras relativas al "guion" presente en las imágenes: la fiesta de cumpleaños, conectores causales (ej., porque) y verbos que implican movimiento (ej., vino, conjugación del verbo venir). Estos resultados señalan, por un lado, que las imágenes propiciaron el uso de conectores de tipo causal, aspecto resaltado en otras investigaciones (e.j., Alarcon-Neve \& Auza-Benavides, 2015; Shapiro \& Hudson, 1991), indicando la comprensión de secuencias causales (Bornens, 1990; Pressley et al., 1994; Snow \& Ninio, 1986). Y el uso de verbos refleja la interpretación dinámica de las imágenes (Bornens, 1990).

Las descripciones, por su parte, propiciaron la utilización de sustantivos, específicamente nombres de animales que aparecían en las imágenes (ej., loro, serpiente), combinadas con deícticos que denotan localización (acá, este). La utilización de estas palabras no refleja la interpretación de una actividad o cambio de estado, lo que sería indicador de una interpretación estática y aislada de cada una de las imágenes (Berman \& Katzenberger, 2004; Bornens, 1990). El análisis de contenido de las producciones más características permite observar que la descripción es más extensa y con mucho detalle; describe en profundidad las imágenes y las características de los personajes, mientras la narración es más escueta y con menos detalles sobre los personajes. Esto nos hace pensar que las narraciones y las descripciones son producciones diferentes, por lo que la descripción no precedería a la narración. Es por esto por lo que clasificamos las producciones como descripciones y no como pre-narraciones, como ocurre en trabajos previos (Berman \& Katzwnberger, 2004).

Vale aclarar que en este estudio utilizamos la categoría de descripción en sentido amplio haciendo alusión tanto a la enumeración de elementos que aparecen en las imágenes y la explicación acerca de sus características, como a la presentación de conflictos o sentimientos representados en las imágenes. De hecho, algunas descripciones presentan acciones o conflictos, sin embargo, estas acciones no se retoman en las imágenes siguientes. Es decir, no son integradas en una narración sino, a nuestro modo de ver, son solamente descritas. Es posible que esto ocurra debido a que ambos sets de imágenes, realistas y no realistas, reflejan conflictos o estados emocionales (por ejemplo, podemos observar a los personajes con rostros tristes), a diferencia de otros estudios que no variaron el nivel de realismo de las imágenes sino la presentación o no de imágenes que reflejen conflicto en la secuencia (Shapiro \& Hudson, 1991). En este sentido, una descripción exhaustiva de estas imágenes implicaría, además de enumerar elementos y características de los mismos, explicitar el tipo de acciones o conflictos que se reflejan en ellas.

Probablemente, las descripciones contribuyan al desarrollo de procesos cognitivos que implican poner el foco en aspectos puntuales de una representación para así vincular esta información con entidades existentes en la vida real. Es decir, las imágenes más realistas facilitarían el insight representacional, la comprensión del vínculo entre imágenes y referentes (DeLoache \& Marzolf, 1992). Específicamente, 
Pág 98

Es posible que las imágenes menos realistas propicien el distanciamiento cognitivo (Siegel, 1997), un desapego del aquí y ahora para crear historias de ficción sobre aspectos que no han ocurrido en la realidad $y$, a veces, es difícil o imposible que ocurran. la utilización de imágenes más realistas podría propiciar el desarrollo de la función referencial y el aprendizaje. Esta interpretación es coherente con trabajos previos que destacan la importancia del realismo de las imágenes al momento de utilizarlas para enseñar palabras y conceptos a niños/as pequeños (ej., Ganea et al., 2009, Ganea, et al., 2008; Mareovich \& Peralta, 2015, 2016; Mareovich et al., 2015).

Por otra parte, es posible que las imágenes menos realistas propicien el distanciamiento cognitivo (Siegel, 1997), un desapego del aquí y ahora para crear historias de ficción sobre aspectos que no han ocurrido en la realidad y, a veces, es difícil o imposible que ocurran. Este distanciamiento podría favorecer la construcción de sentido (Bruner, 2013). Asimismo, el desarrollo de la narración de ficción estaría vinculado con el desarrollo de la simulación en la infancia, la capacidad de concebir alternativas diferentes a la realidad. Esta capacidad es el molde para el desarrollo de la imaginación, proceso cognitivo sofisticado que se complejiza a lo largo del desarrollo (Harris, 2005).

La posibilidad de leer el significado narrativo en imágenes no realistas se desarrolla, probablemente, gracias a la experiencia del niño/a en su contexto sociocultural, específicamente en las interacciones con libros ilustrados (ej. Bruner, 1986; Nelson, 1996; Paris \& Paris, 2003). Estas historias gráficas, así como las historias que aparecen en otros formatos como videos, presentan personajes de ficción que son casi siempre no realistas y antropomórficos.

Los niños y niñas aprenden a lo largo del desarrollo a interpretar diversos tipos de imágenes y a utilizar estas imágenes como medio para llevar a cabo diversas tareas. Por lo tanto, al desafío de interpretar de manera referencial las imágenes o de utilizarlas para construir historias, se suma la dificultad de discernir qué tipo de tarea realizar a partir de estas representaciones.

En suma, las diferencias encontradas en los tipos de producciones de los niños/ as según el tipo de imágenes a las que fueron expuestos, realistas y no realistas, se vinculan al tipo de estructura del relato y al ordenamiento de las imágenes que posibilita la construcción o no de relatos integrados. Esto indica que el tipo de imágenes influye en el tipo de producciones que realizan los niños/as. Estos resultados son consecuentes con investigaciones que destacan el desafío que implica para niños/ as pequeños "leer el significado" de cada imagen e integrar estos significados en una producción coherente (ej., Berman \& Katzenberger, 2004; Bornens, 1990; Paris \& Paris, 2003).

Este trabajo nos invita a reflexionar sobre qué tipo de imágenes o libros utilizar en interacciones con niños y niñas pequeños y para qué fines. Los resultados de esta investigación sugerirían que la elección del material dependerá del tipo de actividad planificada. ¿Estamos intentando propiciar la construcción de relatos de ficción? ¿Utilizamos los cuentos para transmitir conocimientos sobre el mundo? En este sentido, sería interesante proporcionar contextos ricos y variados, en donde niños y niñas encuentren representaciones en diversos formatos y participen de distintos tipos de interacciones. 


\section{Referencias}

Alam, F. (2015). La construcción interaccional de narrativas de ficción entre niños de distintas edades. Un estudio con niños de poblaciones urbano marginadas. Interdisciplinaria, 32(1), 31-49. Recuperado de: http://www.redalyc.org/articulo. oa?id=18041090002

Alam, F., \& Rosemberg, C.R. (2016). ¡Uy, no! ¡Mirá lo que pasó!? Uso de recursos evaluativos en narrativas de ficción por niños pequeños de poblaciones urbano-marginadas. Íkala, 21, 281-297. doi: http://dx.doi.org/10.17533/udea.ikala. $\underline{\mathrm{v} 21 \mathrm{n} 03 \mathrm{a} 03}$

Alarcon-Neve, L. J., \& Auza-Benavides, A. (2015). Uso y función de nexos en la subordinación y coordinación. Evidencia de dos tareas narrativas de niños mexicanos de primero de primaria. En E.P. Velázquez Patiño \& I. Rodriguez Sánchez (Eds.). Estudios de lingüística funcional (pp. 223-251). México: Editorial Universitaria UAQ (Col. Academia, Serie Nodos).

Aluja, T., \& Morineau, A. (1999). Aprender de los datos: el análisis de componentes principales. Una aproximación desde el Data Mining. Barcelona: Ediciones Universitarias de Barcelona.

Beaudouin, V. (2016). Retour aux origines de la statistique textuelle: Benzécri et l'école française d'analyse des données. Statistical Analysis of Textual Data - JADT 2016, 17-27.

Berman, R. A., \& Katzenberger, I. (2004). Form and function in introducing narrative and expository texts: A developmental perspective. Discourse Processes, 38, 57-94. doi: http://dx.doi.org/10.1207/s15326950dp3801 3

Bornens, M. (1990). Problems brought about by "reading" a sequence of pictures. Journal of Experimental Psychology, 49, 189-226. doi: http://dx.doi.org/10.1016/00220965(90)90055-D

Brown, A. L. (1975). Recognition, reconstruction and recall of narrative sequences by preoperational children. Child Development, 46, 156-166. doi: http://dx.doi. org/10.2307/1128844

Brown, A. L., \& French, L. A. (1976). Construction and regeneration of logical sequences using causes or consequences as point of departure. Child Development, 41, 930940. doi: http://dx.doi.org/10.2307/1128428

Bruner, J. (1986). El habla del niño. Barcelona: Paidós.

Bruner, J. (2013). La fábrica de historias. Derecho, literatura, vida. Buenos Aires: Fondo de Cultura Económica.

Carmiol, A. M., \& Sparks, A. (2014). Narrative development across cultural contexts: Finding the pragmatic in parent - child reminiscing. En D. Mathews (Ed). Pragmatic Development in First Language Acquisition (pp. 279-293). Amsterdam: John Benjamins.

DeLoache, J. S. (2004). Becoming symbol-minded. Trends in Cognitive Sciences, 8, 66-70. doi: http://dx.doi.org/10.1016/j.tics.2003.12.004

DeLoache, J. S., \& Burns, N. (1994). Early understanding of the representational function of pictures. Cognition, 52, 83-110. doi: http://dx.doi.org/10.1016/00100277(94)90063-9

DeLoache, J. S., \& Marzolf, D. (1992). When a picture is not worth a thousand words: Young children's understanding of pictures and models. Cognitive Development, 7, 317-329. doi: http://dx.doi.org/10.1016/0885-2014(92)90019-N

DeLoache, J. S., Peralta, O.A., \& Anderson, K. N. (1999). Multiple factors in early symbol use: Instructions, similarity, and age in understanding a symbol-referent relation. Cognitive Development, 14, 299-312. doi: http://dx.doi.org/10.1016/s0885$\underline{2014(99) 00006}$ 
DeLoache, J. S., Pierroutsakos, S., \& Troseth, G. (1996). The three R's of pictorial competence. En R. Vasta (Ed.), Annals of child development (Vol. 12, pp. 1-48).

Fivush, R., Haden, C. A., \& Reese, E. (2006). Elaborating on elaborations: The role of maternal reminiscing style in cognitive and socioemotional development. Child Development, 77, 1568-1588. doi: http://dx.doi.org/10.1007/s10615-0 06-0065-1

Ganea, P. A., Allen, M., Butler, L., Carey, S. \& DeLoache, J. S. (2009). Toddlers' referential understanding of pictures. Journal of Experimental Child Psychology, 104, 283295. doi: http://dx.doi.org/10.1016/j.jecp.2009.05.008

Ganea, P. A., Bloom-Pickard, M., \& DeLoache, J. S. (2008). Transfer between picture books and the real world by very young children. Journal of Cognition and Development, 9, 46-66. doi: http://dx.doi.org/10.1080/15248370701836592

Glaser, B., \& A. Strauss (1967). The discovery of grounded theory. Chicago: Aldine Publishing Company.

Harris, P. (2005). El funcionamiento de la imaginación. Buenos Aires: Fondo de Cultura Económica.

Hess, K., \& Prado, M.L. (2013). ¿Te leo un cuento? La lectura de relatos en el desarrollo narrativo de niños en edad preescolar. En A. Auza \& K. Hess (Eds.) ¿Qué me cuentas? Narraciones y desarrollo lingüístico en niños hispanohablantes (pp. 111-140). México: DeLaurel-UAQ-Hospital General Manuel Gea González.

Karmiloff-Smith, A. (1985). Language and cognitive processes from a developmental perspective. Language and Cognitive Processes, 1, 61-85. doi: http://dx.doi. org/10.1080/01690968508402071

Mareovich, F., \& Peralta, O.A. (2015). La Comprensión Referencial Temprana: Aprendiendo Palabras a Través de Imágenes con Distinto Nivel de Iconicismo. Psykhe, 24, 1-11. doi: http://dx.doi.org/10.7764/psykhe.24.1.661

Mareovich, F., \& Peralta, O.A. (2016). Learning an adjective. The impact of descriptive information / Aprendiendo un adjetivo. El impacto de la información descriptiva. Infancia y Aprendizaje, 39(3), 528-559. doi: http://dx.doi.org/10.1080/02103702. $\underline{2016.1189120}$

Mareovich, F., Taverna, A., \& Peralta, O. A. (2015). Enseñando palabras mediante libros ilustrados: El aprendizaje temprano de sustantivos y adjetivos. Interdisciplinaria, 32, 89-107. doi: http://dx.doi.org/10.16888/interd.2015.32.1.5

McCabe, A., \& Peterson, C. (1991). Developing narrative structure. Hillsdale, NJ: Erlbaum. Moscoloni, N. (2005). Las nubes de datos. Métodos para analizar la complejidad. Rosario: UNR Editora.

Nelson, K. (1996). Language in cognitive development. Cambridge: Cambridge University Press.

Ninio, A., \& Bruner, J. (1978). The achievement and antecedents of labeling. Journal of Child Language, 5, 1-15. doi: https://doi.org/10.1017/S0305000900001896

Paris, A. H., \& Paris, S. G. (2003). Assessing narrative comprehension in young children. Reading Research Quarterly, 38, 36 -76.doi: http://dx.doi.org/10.1598/ RRQ.38.1.3

Peralta, N., Castellaro, M., \& Santibáñez, C. (2020). El análisis de datos textuales como metodología para el abordaje de la argumentación: una investigación con estudiantes de pregrado en universidades chilenas. Íkala, Revista de Lenguaje y Cultura, 25(1), 209-227. http://doi.org/10.17533/udea.ikala.v25n01a02

Peterson, C., \& McCabe, A. (1983). Developmental Psycholinguistics: Three Ways of Looking at a Child's Narrative. New York: Plenum Press.

Peterson, C., \& McCabe, A. (1994). A social interactionist account of developing decontextualized narrative skill. Developmental Psychology, 30, 937 - 948. doi: http:// dx.doi.org/10.1037/0012-1649.30.6.937 
Piaget. J. (1946). Le développement de la notion du temps chez L'enfant. Paris: Presses Universitaires de France.

Pressley, M., Almasi, J., Schuder, T., Bergman, J., Hite, S., El-Dinary, P. B., \& Brown, R. (1994). Transactional instruction of comprehension strategies: The Montgomery County, Maryland, SAIL program. Reading and Writing Quarterly, 10, 5-19. doi: http://dx.doi.org/10.1080/1057356940100102

Schmidt, C. R., Paris, S. G., \& Stober, S. (1979). Inferential distance and children's memory for pictorial sequences. Developmental Psychology, 15(4), 395-405. doi: https://doi.org/10.1037/0012-1649.15.4.395

Schmidt, C. R., \& Paris, S. G. (1978). Operativity and reversibility in children's understanding of pictorial sequences. Child Development, 49, 1219-1222. doi: https://doi.org/10.2307/1128764

Shapiro, L. R., \& Hudson, J. A. (1991). Tell me a make-believe story: coherence and cohesion in young children's picture-elicited narratives. Development Psychology, 27, 960-74. doi: https://doi.org/10.1037/0012-1649.27.6.960

Sigel, I. E. (1978). The development of pictorial comprehension. En B. Randhawa\& W. Coffman (Eds.) Visual learning, thinking and communication, (pp. 93-111). Nueva York: Academic Press.

Sigel, I. E. (1997). Modelo de distanciamiento y desarrollo de la competencia representativa. Infancia y Aprendizaje, 78, 13-29. doi: https://doi. org/10.1174/021037097761403118

Snow, C. E., \& Goldfield, B. (1983). Turn the page please: Situation specific language acquisition. Journal of Child Language, 10, 551-570. doi: https://doi.org/10.1017/ S0305000900005365

Snow, C. E., \& Ninio, A. (1986). The contracts of literacy: What children learn from learning to read books. En W.H. Teale \& E. Sulzby (Eds.), Emergent literacy: Writing and reading (pp. 116-138). Norwood, NJ: Ablex.

Stein, N.L., \& Glenn, C.G. (1979). An analysis of story comprehension in elementary school children. En R. Friedle (Ed.), New directions in discourse processing. Norwood, NJ: Ablex.

Strauss, A. L., \& Corbin, J. (1990). Basics of qualitative research: Grounded theory procedures and techniques. London, Reino Unido: Sage.

Trautner, H., \& Milbrath, C. (2008). Children's knowledge about pictures, drawins, and art. En C. Milbrath y H. Trautner (Eds.), Children's understanding and production of pictures, drawing, and art (pp. 3-18). Cambridge, MA: Hogrefe \& Huber. 